\title{
Coconut: Natural Source of Potential Anti Cancer Agent
}

\author{
Dr. Amit Ghosh
}

\begin{abstract}
The current strategy of drug development is time consuming and expensive. This contrasts sharply with the vision of affordable drug development. The costly and the lengthy paradigm of drug discoveries are major obstacles for combating with rapidly emerging and sporadic diseases. The dichotomy between the urgent requirement of affordable treatment development and the hindrance it faces is apparent in several recent literatures which reflects the importance of drug repurposing and development of botanical drugs. Consistent with this idea, past few decades of studies on Cocos nucifera has yielded a fair knowledge about the anticancer potential of coconut products. The aggregate knowledge is undeniably positive and offers the novel avenues for the therapeutics and affordable drug development. This article highlights the link between coconut products and its anticancer effects.
\end{abstract}

Keywords: coconut products, anti cancer agent, drug development

\section{Introduction}

One third to half of all pharmaceuticals drug are originally derived from plants. Natural products are the source of $60 \%$ of currently used anticancer products and some of natural products are under clinical trial (http://www.clinicaltrials.gov/). PubMed search shows countless article regarding the health benefit of coconut. Curated preventive role of virgin coconut oil (VCO) and coconut water $(\mathrm{CW})$ in cancer, cardiovascular, neuronal, mental and metabolic diseases are reflected in several in vitro and in vivo studies. But underlining causes of these therapeutic effects are yet to be explored. The virgin coconut oil and green coconut water have interesting anti-cancer activity. In spite of the miraculous health beneficial effect and potential marketing opportunity, Cocos nucifera products did not significantly translated into everyday health care products and medicines. This is because most effort of drug development efforts are focused on synthetic compounds.

After publication of the FDA's industry guidelines for botanical drug product in June 2004, first botanical product Veregen (sinecatechins) was approved by FDA on $31^{\text {st }}$ October 2006 for marketing. Veregen was prepared from green tea leaves and approved for the topical treatment of perianal and genital condyloma. Approval of veregen by FDA was instrumental in the steadily growing interest for launching of other botanical drug products. Many botanical products are used over thousands of years (due to its beneficial purpose) but according to present FDA rules, identifying the different medicinal properties of its compounds and using them for the formulation of health care products will help in getting approval for its marketing for the treatment of specific health condition. New thinking is needed to address this challenge.

Department of Physiology, All India Institute of Medical Sciences, Bhubaneswar, India.

Email: idamit2010@gmail.com 
In this review we revisit the history of anticancer potential of VCO and summarize the recent finding to expand our understanding about anticancer effect of coconut water. This information will help to understand the mechanism of action and also encourage other research groups to conduct further translational research in this field.

Much remains to be discovered with regard to nutritional based treatment. But interpreting the published literature clearly indicates that coconut products function like double edges of a sword - Nutritionally it can prevent cancer and it is also a source of potent anticancer molecules (Table $2 \& 3$ ). Anticancer properties of coconut oil were also reported by Lim-Sylianco in 1987, in his published 50 years literature review and by Cohen et al. in 1986. Coconut oil is also anti-carcinogenic $(1,2)$.

As any promising domain of biology it is better to start with phenotype and then ask "why," to explore the underlining causes. Anticancer properties of Virgin coconut oil (VCO) are imparted because of its high percentage of medium chain fatty acid. The coconut oil which is composed of $92 \%$ saturated fatty acid, are predominantly medium chain fatty acids in the form of triglyceride (MCT) and 8\% of unsaturated consisting of oleic and linoleic acid as triglycerides. Due to high fat and low carbohydrate composition it can be considered as a ketogenic diet (KD), consumption of which forces the body to burn fat rather than carbohydrate. Ketogenic diet reduces the frequency of epileptic seizures and includes treatment for several rare metabolic disorders. Several published articles have reported the anticancer effect of ketogenic diet (Table 1).

Due to inefficiency of cancer cell in processing ketone bodies for energy, ketogenic diet are effective for cancer treatment. Consumption of ketogenic diet results in carbohydrate restriction and consequently decreases the serum glucose and insulin level followed by increase in lipolysis. Fatty acid activate the peroxisome proliferator-activated receptor $\alpha(\mathrm{PPAR} \alpha)$. PPAR $\alpha$ increase fatty acid oxidation and ketogenesis as well as inhibit fatty acid synthesis and glycolysis $(13,14)$.

Both Insulin and IGF-1 activates the phosphatidylinositol-3 kinase (PI3K)-Aktmammalian target of rapamycin complex 1 (mTORC1) signaling pathway. This pathway promotes sustained proliferative signaling, resisting cell death and modulates cellular mechanism which are the hall mark of cancer. Ketogenic diet means carbohydrate and protein restriction which results in drop of insulin level and less bioavailability of IGF-1 respectively. As a result (PI3K)-Akt-mTORC1 signaling pathway are not activated (16). mTORC1 also inhibit the PPAR $\alpha$ and downregulate ketogenesis (17). Interestingly ketogenic diet also modulates the cell signaling pathways, which are also the target of some anticancer drugs (14). Adding fresh coconut into daily dishes will be the nontoxic alternative cancer treatments.

It was reported long before that coconut oil is composed of fatty acids, sterols and cytokinins. Among sterol in coconut oil, betasitosterol are most abundant. Oral bioavailability of $\beta$-sitosterol is $36.9 \%$. It inhibits proliferation and induces apoptosis in breast cancer cell MCF7 and human leukemic U937 cells $(18,19,20)$. It activates caspase- 3 and $\mathrm{Bax} / \mathrm{Bcl}-2$ ratio U937 cells.

Cytotoxicity of $\beta$-sitosterol against HT-29 cell line (colon carcinoma) has also been also reported (21). It shows inhibitory activity and IC50 value in different cancer cell lines as follows (control: adriamycin, MCF-7, IC50 $=1.5 \pm 0.2 \mu \mathrm{M} ; \quad$ K562, IC $50=0.07 \pm 0.01 \mu \mathrm{M}$; Bowes, $\quad$ IC $50=0.45 \pm 0.01 \mu \mathrm{M}$; $\quad$ T24S, IC50 $=5.8 \pm 0.6 \mu \mathrm{M} ; \quad$ A549, IC $50=15.8 \pm 6.7 \mu \mathrm{M})$. Though several target of $\beta$ sitosterol has been reported but its detail anticancer mechanism of action are yet to be explored $(21,22,23)$.

Delta (5)-avenasterol (fucosterol) inhibits rat lens aldose reductase (RLAR), human recombinant aldose reductase (HRAR), protein tyrosine phosphatase 1B (PTP1B), and $\alpha$ glucosidase. As it inhibits aldose reductase (AR), it may be a potential molecule for the management of diabetes and diabetes-associated complications (25). Fucosterol decreased activity 
Table 1. Anticancer role of Ketogenic diet and MCT in animal model

\begin{tabular}{|l|l|}
\hline \multicolumn{1}{|c|}{ Anticancer role of ketogenic diet } & References \\
\hline $\begin{array}{l}\text { KD improves the survivability of mouse model of glioma by retarding the tumour } \\
\text { growth, prevents reactive oxygen species (ROS) production and shifts tumour tissue } \\
\text { gene expression profile towards normal tissue gene expression pattern }\end{array}$ & 3 \\
\hline KD also retards tumour growth in mouse xenograft model & 4 \\
\hline $\begin{array}{l}\text { MCT reduces tumour growth and improves nutritional status in GI tract cancer } \\
\text { patients }\end{array}$ & 5,6 \\
\hline Anticancer effect of MCT, may be exerted through the modulation of immune system & 7 \\
\hline $\begin{array}{l}\text { In cachexia-inducing colon adenocarcinoma (MAC16) model, there are marked } \\
\text { reduction in tumour size in animal fed with MCT }\end{array}$ & 8 \\
\hline Coconut oil and MCT shows anticancer effect in mammary tumour incidence & 9 \\
\hline $\begin{array}{l}\text { Coconut oil and MCT shows cancer promoting effect of azoxymethane (AOM)-in rat } \\
\text { colon tumours model }\end{array}$ & 10 \\
\hline $\begin{array}{l}\text { MCT-containing diet also prevent tumour formation in } \\
\text { N-nitrosomethylurea animal mammary tumour model }\end{array}$ & 11,12 \\
\hline
\end{tabular}

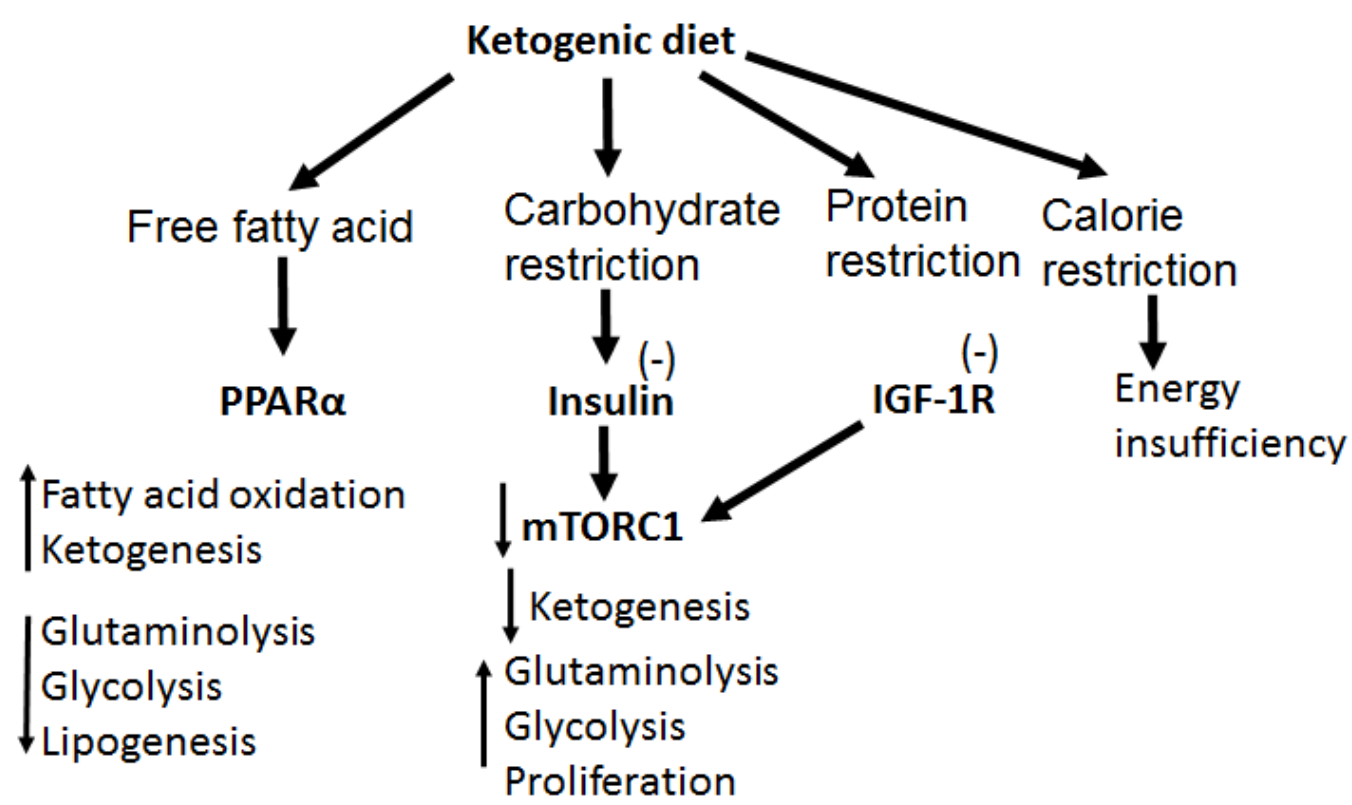

Figure 1. Showing anticancer role of ketogenic diet (15) 
1
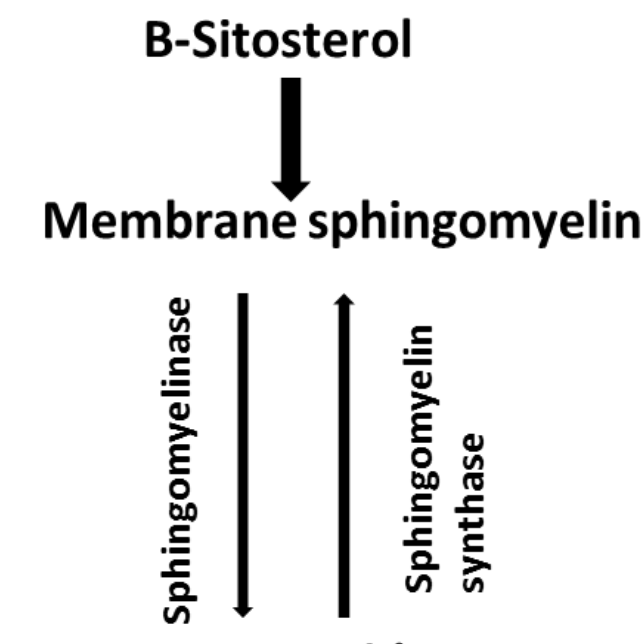

Ceramide

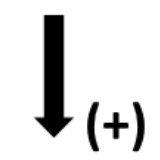

Protein

Phospholipase 2A

$(-)$

\section{Cell}

Proliferation

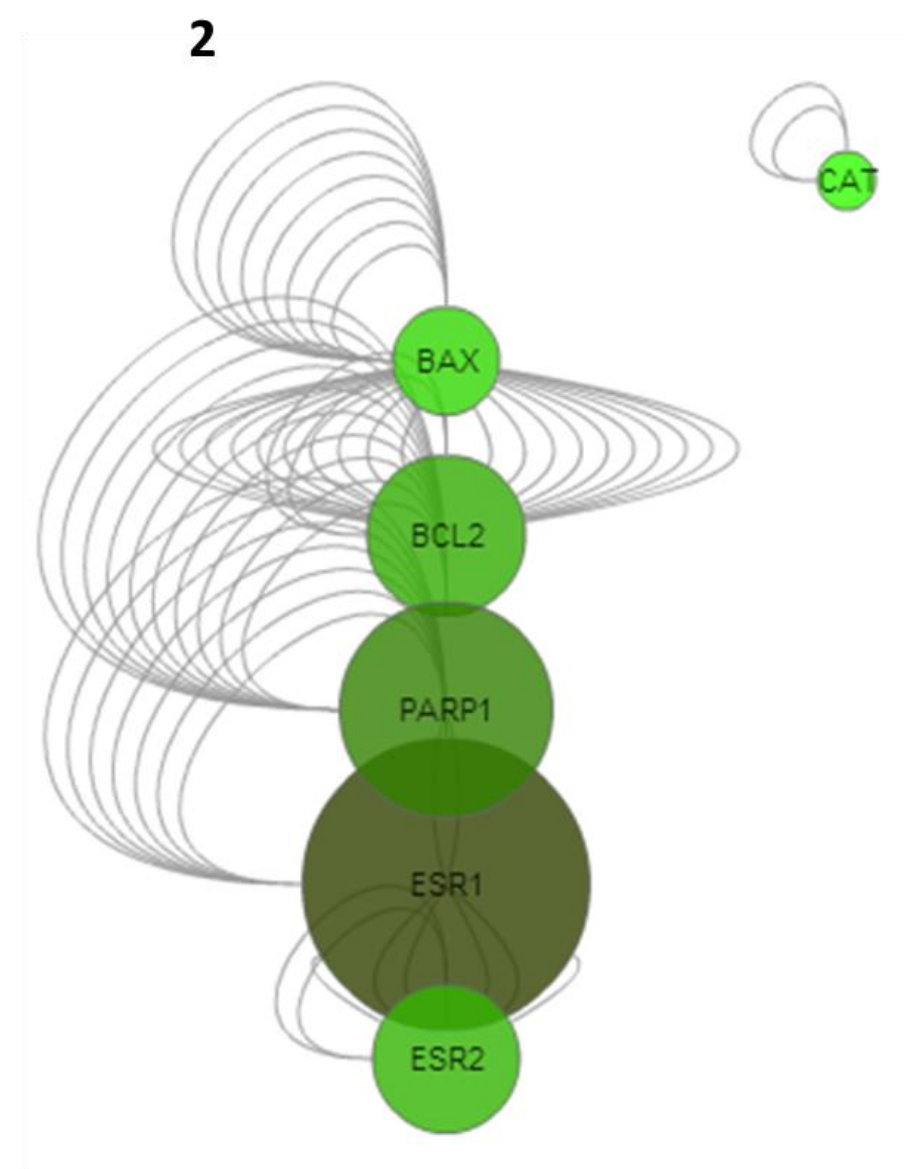

Figure. 2.1 Showing mechanism of anticancer activity of $\beta$-sitosterol. 2.2 Anticancer activity also reflected in interaction (from BioGRID) of $\beta$-sitosterol regulated gene

Table 2. Anticancer effect of sterol and other compounds isolated from VCO and coconut water

\begin{tabular}{|l|l|l|}
\hline \multirow{2}{*}{ Sterol } & \multicolumn{2}{|c|}{ Disease } \\
\cline { 2 - 3 } & Therapeutic (Reported) & Therapeutic (Predicted) \\
\hline$\beta$-sitosterol & Anticancer & \\
\hline Delta (5)-avenasterol & Diabetes Complications & Mediastinal Neoplasms, Lymphoma \\
\hline Stigmasterol & Anticancer & \\
\hline Other compounds & \multicolumn{2}{|l|}{} \\
\hline Gamma-tocotrienol & Anticancer & \\
\hline Oleic acid & Anticancer & \\
\hline
\end{tabular}


Table 3. Anticancer effect of cytokinins present in coconut water

\begin{tabular}{|l|l|}
\hline Cytokinin in coconut water & \multicolumn{1}{|c|}{ Therapeutic (Reported) } \\
\hline N6-isopentenyladenosine & Anticancer \\
\hline N6-Isopentenyladenine & Anticancer \\
\hline $\begin{array}{l}\text { N6 -benzyladenine } \\
\text { or N6-Benzylaminopurine }\end{array}$ & Anticancer \\
\hline N6 -benzyladenosine & Anticancer \\
\hline kinetin & Anticancer \\
\hline kinetin riboside & Anticancer \\
\hline Trans-Zeatin & Anticancer \\
\hline Trans-zeatin riboside & Anticancer \\
\hline Cn-AMP2 Peptide & Anticancer: 1321N1 and U87MG human glioma cell lines \\
\hline
\end{tabular}

of PTPN1 protein and its role in cancer is yet to be explored.

Some cytokinins and its derivatives reportedly retard and reduce tumor growth (25). Coconut water contain a large spectrum of cytokinin and some of them are potential anticancer agents (Table 2). Selective killing of cancer cell is still a greatest challenge and needs to be addressed. Research shows Kinetin riboside (KR) have cancer specific cytotoxicity. $\mathrm{KR}$ is present in coconut milk in nanomole level. KR selectively inhibits the proliferation of cancer cells and induces apoptosis. In KR exposed cell, proapoptotic Bax are upregulated and anti-apoptotic Bcl-2 protein are downregulated. Besides, this increases the Cytochrome c level along with procaspase 9 and its active form in KR treated cell may be the underlining cause of anticancer activity $(26,27)$. Another isoprenoid cytokinins, N6isopentenyladenine present in coconut water shows anticancer activity in cell culture based assay $(28,29,30,31,32,33)$. Cytokinin N6isopentenyladenosine (I6A) $($ IC50 $=12.2 \mathrm{mM})$ also inhibits the growth of human breast cancer MCF-7 cells. I6A induces apoptosis in MCF-7 cells by inhibiting the Akt activation and suppresses the nuclear factor kappaB $(\mathrm{NF}-\kappa \mathrm{B})$ pathway $(34,35,36)$. I6A also induces apoptosis in colon cancer cell line through the phosphorylation of c-jun $\mathrm{N}$-terminal kinase (JNK) and consequent phosphorylation of c-jun (37). Anticancer role of N6-Benzylaminopurine (6-BAP) and its derivatives has been reported by several articles. 6-BAP activate protein kinase A (PKA) and stimulates melanogenesis. Melanin pigments prevent skin photocarcinogenesis (38, 39, 40, 41). Another cytokinin, Kinetin modulates aberrant neurofibromatosis type 1 (NF1) pre-mRNA, IKBKAP (inhibitor of kappa light polypeptide gene enhancer in B-cells, kinase complex-associated protein) and other genes splicing and improve exon inclusion (29, $42,43,44)$ and may play a role in cancer prevention.

Trans-Zeatin inhibit UVB-induced MMP-1 expression and may have anticancer role (45). The latest addition is anionic peptide $\mathrm{Cn}$-AMP2 (TESYFVFSVGM) which was isolated from green coconut water and it inhibits the proliferation of $1321 \mathrm{~N} 1 \quad\left(\mathrm{IC}_{50}=1.25 \mathrm{mM}\right)$ and U87MG $\left(\mathrm{IC}_{50}=1.85 \mathrm{mM}\right)$ human glioma cell lines. $C n$-AMP2 has anticancer activity against human glioblastoma and may be used for treatment against other cancers (46). 
Finally I perform the pathways and diseases enrichment analyses for 5 cytokinins (kinetin riboside, kinetin, isopentenyladenosine, Isopentenyladenine, Benzylaminopurine). Result are following:

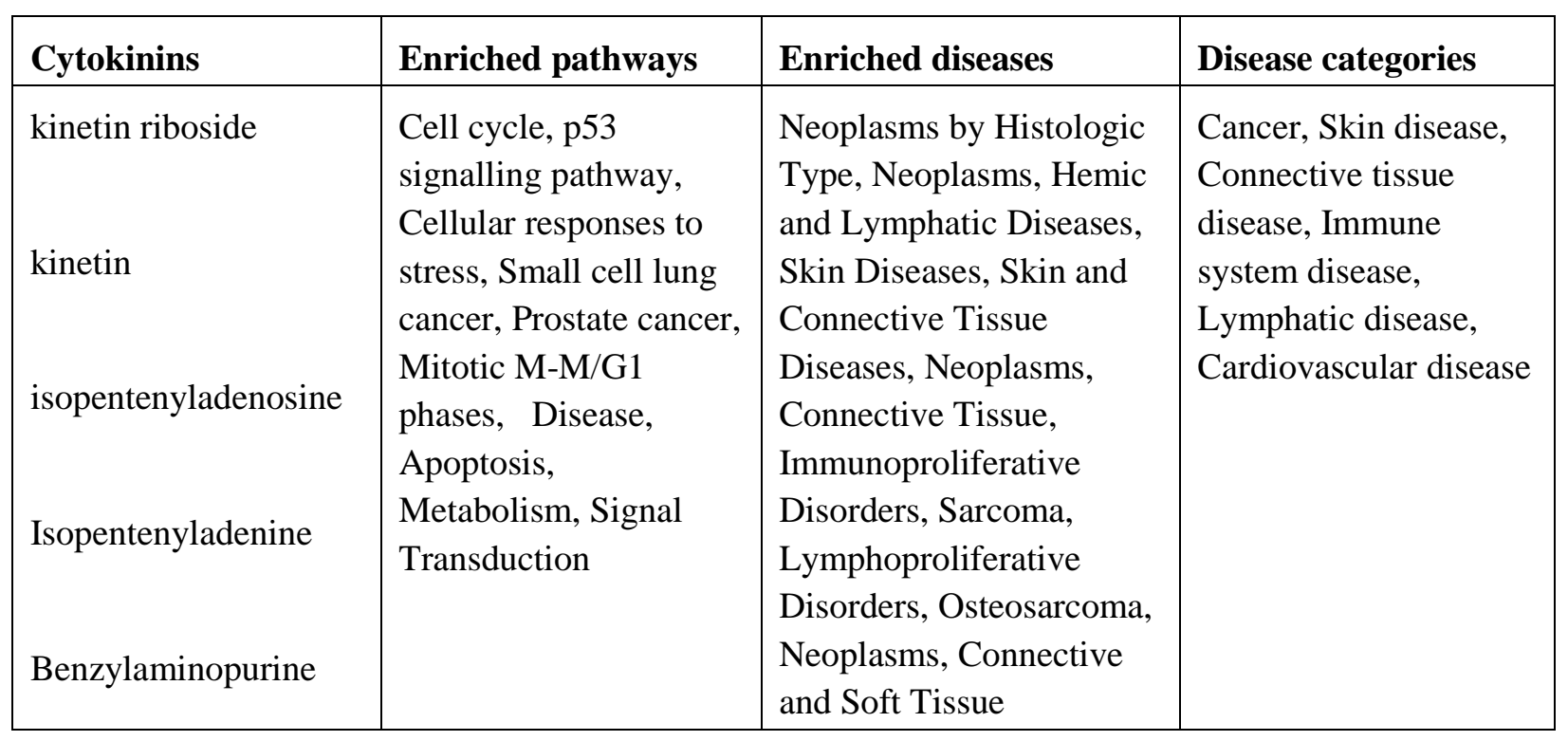

These results highlight the previously unnoticed link between coconut products and its promising anticancer effects. It also indicates the possible other therapeutic potential of cytokinin. We are unable to analyze the pathways and diseases enrichment for Trans-Zeatin, Transzeatin riboside, benzyladenosine due to insufficient information. Based on accumulating information, it is clear that the beneficial effects of some cytokinins are yet to be explored. Incorporating this modern knowledge into design the novel treatment could be effective in combating cancer and other diseases.

\section{References}

Casati S, Ottria R, Baldoli E, Lopez E, Maier JA, Ciuffreda P. Effects of cytokinins, cytokinin ribosides and their analogs on the viability of normal and neoplastic human cells. Anticancer Res. 2011 Oct; 31(10):3401-6.

Casati S, Ottria R, Baldoli E, Lopez E, Maier JA, Ciuffreda P. Effects of cytokinins, cytokinin ribosides and their analogs on the viability of normal and neoplastic human cells. Anticancer Res. 2011 Oct; 31(10):3401-6.
Chai JW, Kuppusamy UR, Kanthimathi MS. Beta-sitosterol induces apoptosis in MCF7 cells. Malays J Biochem Molecular Bio. 2008; 16:28-30.

Chen FM, Wang JY, Sun LC, Juang RF, Huang TJ, Hsieh JS. Efficacy of medium-chain triglycerides compared with long-chain triglycerides in total parenteral nutrition in patients with digestive tract cancer undergoing surgery. Kaohsiung J Med Sci. 2005 Nov; 21(11):487-94.

Cohen LA, Thompson DO, Maeura Y, Weisburger JH. Influence of dietary medium-chain triglycerides on the development of $\mathrm{N}$-methylnitrosoureainduced rat mammary tumors. Cancer Res. 1984 Nov; 44(11):5023-8.

Cohen LA, Thompson DO. The influence of dietary medium chain triglycerides on rat mammary tumor development. Lipids. 1987 Jun; 22(6):455-61.

Craig-Schmidt M, White MT, Teer P, Johnson J, Lane HW. Menhaden, coconut, and corn oils and mammary tumor incidence in $\mathrm{BALB} / \mathrm{c}$ virgin female mice treated with DMBA. Nutr Cancer. 1993; 20(2):99-106. 
Cullingford TE. The ketogenic diet; fatty acids, fatty acid-activated receptors and neurological disorders. Prostaglandins Leukot Essent Fatty Acids. 2004 Mar; 70(3):253-64.

Cullingford, T. E. (2004). The ketogenic diet; fatty acids, fatty acid activated receptors and neurological disorders. Prostaglandins, Leukotrienes and Essential Fatty Acids, 70, 253-264.

Dudzik P, Dulińska-Litewka J, Wyszko E, Jędrychowska P, Opałka M, Barciszewski J, Laidler P. Effects of kinetin riboside on proliferation and proapoptotic activities in human normal and cancer cell lines. J Cell Biochem. 2011 Aug; 112(8):2115-24.

Dvořák Z, Starha P, Trávníček Z. Evaluation of in vitro cytotoxicity of 6benzylaminopurine carboplatin derivatives against human cancer cell lines and primary human hepatocytes. Toxicol In Vitro. 2011 Apr; 25(3):652-6.

Ge L, Yong JW, Tan SN, Yang XH, Ong ES. Analysis of some cytokinins in coconut (Cocos nucifera L.) water by micellar electrokinetic capillary chromatography after solid-phase extraction. J Chromatogr A. 2004 Sep 3; 1048(1):119-26.

Ge L, Yong JW, Tan SN, Yang XH, Ong ES. Analysis of some cytokinins in coconut (Cocos nucifera L.) water by micellar electrokinetic capillary chromatography after solid-phase extraction. J Chromatogr A. 2004 Sep 3; 1048(1):119-26.

Griffaut B, Bos R, Maurizis JC, Madelmont JC, Ledoigt G. Cytotoxic effects of kinetin riboside on mouse, human and plant tumour cells. Int J Biol Macromol. 2004 Aug; 34(4):271-5.

Grudzien P, Lo S, Albain KS, Robinson P, Rajan P, Strack PR, Golde TE, Miele L, Foreman KE. Inhibition of Notch signaling reduces the stem-like population of breast cancer cells and prevents mammosphere formation. Anticancer Res. 2010 Oct; 30(10):3853-67.
Hanahan D, Weinberg RA. Hallmarks of cancer: the next generation. Cell. 2011 Mar 4; 144(5):646-74.

Hims MM, Ibrahim EC, Leyne M, Mull J, Liu L, Lazaro C, Shetty RS, Gill S, Gusella JF, Reed R, Slaugenhaupt SA. Therapeutic potential and mechanism of kinetin as a treatment for the human splicing disease familial dysautonomia. J Mol Med (Berl). 2007 Feb; 85(2):149-61.

Jung HA, Islam MN, Lee CM, Oh SH, Lee S, Jung JH, Choi JS. Kinetics and molecular docking studies of an anti-diabetic complication inhibitor fucosterol from edible brown algae Eisenia bicyclis and Ecklonia stolonifera. Chem Biol Interact. 2013 Oct 25; 206(1):55-62.

Kim S, Lee J, Jung E, Lee J, Huh S, Hwang H, Kim Y, Park D. 6-Benzylaminopurine stimulates melanogenesis via cAMPindependent activation of protein kinase A. Arch Dermatol Res. 2009 Mar; 301(3):253-8.

Kimoto Y, Tanji Y, Taguchi T, Sugimoto T, Watanabe T, Tsukamoto $\mathrm{F}$, Kim S, Yoneda K, Takamura Y, Izukura M, Shiba E, Takai S. Antitumor effect of mediumchain triglyceride and its influence on the self-defense system of the body. Cancer Detect Prev. 1998; 22(3):219-24.

Klement RJ, Champ CE. Calories, carbohydrates, and cancer therapy with radiation: exploiting the five R's through dietary manipulation. Cancer Metastasis Rev. 2014 Mar; 33(1):217-29.

Laezza C, Caruso MG, Gentile T, Notarnicola M, Malfitano AM, Di Matola T, Messa C, Gazzerro P, Bifulco M. N6isopentenyladenosine inhibits cell proliferation and induces apoptosis in a human colon cancer cell line DLD1. Int $\mathbf{J}$ Cancer. 2009 Mar 15; 124(6):1322-9.

Laezza C, Malfitano AM, Di Matola T, Ricchi P, Bifulco M. Involvement of Akt/NF- $\mathrm{BB}$ pathway in N6-isopentenyladenosineinduced apoptosis in human breast cancer 
cells. Mol Carcinog. 2010 Oct; 49(10):892-901.

Lim Sylianco C.Y., Anticarcinogenic effects of coconut oil. Phillip. J. Coconut Studies, 198712 (2) 89-102. 65. Cohen L. A., Thompson D. O., Maeura, Choi K., Blank M. E., Rose D. P., Dietary fat and mammary cancer.

Manayi A, Saeidnia S, Ostad SN, Hadjiakhoondi A, Ardekani MR, Vazirian M, Akhtar Y, Khanavi M. Chemical constituents and cytotoxic effect of the main compounds of Lythrum salicaria L. Z Naturforsch C. 2013 Sep-Oct; 68(9-10):367-75.

Moon HJ, Finney J, Xu L, Moore D, Welch DR, Mure M. MCF-7 cells expressing nuclear associated lysyl oxidase-like 2 (LOXL2) exhibit an epithelial-to-mesenchymal transition (EMT) phenotype and are highly invasive in vitro. J Biol Chem. 2013 Oct 18; 288(42):30000-8.

Naito A, Suzuki A, Ueda S, Nomoto H, Toriyama-Baba H, Asamoto M, Tsuda H. Preferential mammary carcinogenic effects of 2-amino-1-methyl-6-phenylimidazo [4,5-b]pyridine $(\mathrm{PhIP})$ in human c-Ha-ras proto-oncogene transgenic rats. Cancer Sci. 2004 May; 95(5):399-403.

Otto C, Kaemmerer U, Illert B, Muehling B, Pfetzer N, Wittig R, Voelker HU, Thiede A, Coy JF. Growth of human gastric cancer cells in nude mice is delayed by a ketogenic diet supplemented with omega-3 fatty acids and medium-chain triglycerides. BMC Cancer. 2008 Apr 30; 8: 122.

Park C, Moon DO, Rhu CH, Choi BT, Lee WH, Kim GY, Choi YH. $\beta$-sitosterol induces antiproliferation and apoptosis in human leukemic U937 cells through activation of caspase-3 and induction of $\mathrm{Bax} / \mathrm{Bcl}-2$ ratio. Biol Pharm Bull. 2007; 30:1317-23.

Plentz R, Park JS, Rhim AD, Abravanel D, Hezel AF, Sharma SV, Gurumurthy S, Deshpande V, Kenific C, Settleman J, Majumder PK, Stanger BZ, Bardeesy N.
Inhibition of gamma-secretase activity inhibits tumor progression in a mouse model of pancreatic ductal adenocarcinoma. Gastroenterology. 2009 May; 136(5):1741-9.e6.

Prabhu S, Dennison SR, Mura M, Lea RW, Snape TJ, Harris F. Cn-AMP2 from green coconut water is an anionic anticancer peptide. J Pept Sci. 2014 Dec; 20(12):90915.

Promoting effects of different dietary fats on $\mathrm{N}$ nitrosomethylureainduced rat mammary tumorigenesis. J. Natl. Cancer Inst., 1986 77 (1) 33- 42.

Pros E, Fernández-Rodríguez J, Benito L, Ravella A, Capellá G, Blanco I, Serra E, Lázaro C. Modulation of aberrant NF1 pre-mRNA splicing by kinetin treatment. Eur J Hum Genet. 2010 May; 18(5):614-7.

Rajabi M, Signorelli P, Gorincioi E, Ghidoni R, Santaniello E. Antiproliferative activity of N6-isopentenyladenosine on MCF-7 breast cancer cells: cell cycle analysis and DNAbinding study. DNA Cell Biol. 2010 Nov; 29(11):687-91.

Reddy BS, Maeura Y. Tumor promotion by dietary fat in azoxymethane-induced colon carcinogenesis in female F344 rats: influence of amount and source of dietary fat. J Natl Cancer Inst. 1984 Mar; 72(3):745-50.

Saeidnia S, Manayi A, Ahmad R. Goharil A. R., Abdollahi M. The Story of Beta-sitosterolA Review. European Journal of Medicinal Plants, 4(5): 590-609, 2014.

Sengupta S, Peterson TR, Laplante M, Oh S, Sabatini DM. mTORC1 controls fastinginduced ketogenesis and its modulation by ageing. Nature. 2010 Dec 23; 468(7327):1100-4.

Song W, Jin R, Liu J. Studies on the chemical constituents of stems of Erycibe schmidtii Craib [J]. China journal of Chinese materia medica, 1997, 22(6): 359-360. 
Spitali P, Aartsma-Rus A. Splice modulating therapies for human disease. Cell. 2012 Mar 16; 148(6):1085-8.

Stafford P, Abdelwahab MG, Kim do Y, Preul MC, Rho JM, Scheck AC. The ketogenic diet reverses gene expression patterns and reduces reactive oxygen species levels when used as an adjuvant therapy for glioma. Nutr Metab (Lond). 2010 Sep 10; 7:74.

Tan, S.N.; Yong, J.W.H.; Ge, L. Analyses of Phytohormones in Coconut (Cocos Nucifera L.) Water Using Capillary Electrophoresis-Tandem Mass Spectrometry. Chromatography 2014, 1, 211-226.

Tisdale MJ, Brennan RA. A comparison of longchain triglycerides and medium-chain triglycerides on weight loss and tumour size in a cachexia model. Br $\mathrm{J}$ Cancer. 1988 Nov; 58(5):580-3.
Wolters U, Keller HW, Becker R, Stickeler P, Dahlmeyer M, Müller JM. Influence of various fatty acids on tumour growth in total parenteral nutrition. Eur Surg Res. 1994; 26(5):288-97.

Yang B, Ji C, Kang J, Chen W, Bi Z, Wan Y. Trans-Zeatin inhibits UVB-induced matrix metalloproteinase-1 expression via MAP kinase signaling in human skin fibroblasts. Int J Mol Med. 2009 Apr; 23(4):555-60.

Yong JW, Ge L, Ng YF, Tan SN. The chemical composition and biological properties of coconut (Cocos nucifera L.) water. Molecules. 2009 Dec 9; 14(12):5144-64.

Zhou, J., Xie, G. and Xinjian, Y. (2012) Anticancer active components in TCM. TCM series of active components. Science Press, Bei Jing. 